Peter Arnds

Trinity College of Dublin

Dublin, Ireland

arndsp@tcd.ie

\title{
FROM ELEPHANT GOD TO MAN DOG: HYBRIDITY, MIMICRY, AND THE HOMO SACER IN SALMAN RUSHDIE'S MIDNIGHT'S CHILDREN
}

\begin{abstract}
"Sometimes legends make reality, and become more useful than facts"; "Reality is a question of perspective; the further you get from the past the more concrete and plausible it seems...tiny details assume grotesque proportions. The illusion dissolves, or rather, it becomes clear that the illusion itself is reality" (Salman Rushdie, Midnight's Children, 57; 229)
\end{abstract}

\section{Recommended Citation:}

Arnds, Peter. "From Elephant God to Man Dog: Hybridity, Mimicry, and the Homo Sacer in Salman Rushdie's Midnight's Children”. Metacritic Journal for Comparative Studies and Theory 3.2 (2017): https://doi.org/10.24193/mjcst.2017.4.03

\begin{abstract}
Rushdie's Midnight's Children is a work of pastiche. As such it is typically postmodern, literature patched together from other literary texts. Using Grass's Tin Drum and the German postwar cultural-political situation as a model, Rushdie copies Grass in re-enchanting a secularized country grappling with the memory of genocide through a set of mythological paradigms. By drawing on postcolonial theory and the biopolitical concept of the homo sacer this essay analyses Rushdie's particular brand of what I have termed as mythical realism in view of its close amalgamation of hybridity with mimicry, subversive mockery, and liminality between the human and the animal, typical features of the postmodern novel trying to come to terms with war and genocide. It is the aim of this study to examine the
\end{abstract}


functions of these key features for Rushdie's Midnight's Children for lifting the corks of forgetting and disclosing the concealment of India's past.

Keywords: hybridity, mimicry, homo sacer, body, myth, genocide

Although the narrator of Salman Rushdie's Midnight's Children (1981) makes us believe that it is the tropical heat that gnaws "at the mind's divisions between fantasy and reality" (MC 231) the novel is also a reaction to what it perceives as postcolonial India's "renunciation of deities" (MC 187). Rushdie's novel shares its approach to historical representation specifically with Grass's The Tin Drum (1959), by which it has been directly influenced and with which it has been compared multiple times (Cf. Merivale, Herd, Bader, Gopal, Couto). The parallels between these two authors are legion. Grass's novel about Nazi and post-war Germany no doubt inspired Rushdie to write about a divided country, Pakistan's East and West wings held together by religion and the memory of ethnic cleansing in the East wing to prevent Pakistan from falling apart. Grass uses the image of onions to release tears and memory among post-war Germans. Rushdie on the other hand uses chutney to bring tears to his characters' eyes, the tears of memory. While Saleem Sinai's amnesia is caused by a spittoon hitting the back of his head, Oskar's growth is induced by a stone thrown by his son Kurt and hitting him on the back of his head; the subsequent transformation of both characters is then directly linked to the question of coming to terms with the past of Germany and India. Grass juxtaposes Germans and Poles, and one of Rushdie's central themes is the relationship between Muslims and Hindus. The works of both writers display dense intertextuality and heterogeneity and both have provoked strong reactions from the people who do not agree with their subversive ideology and are repulsed by these texts' images of blasphemy. Arguably though, conservative reactions to Grass's The Tin Drum fade in comparison with the fatwa Khomeini placed on the Indian author after the publication of The Satanic Verses in 1989.

The fact remains, however, that in their satirical engagement with cultural memory both Midnight's Children and The Tin Drum tend to provoke conservative forces. Much like in Grass's novel, Rushdie uses grotesque transformation processes by which he can allude to the dehumanization taking place at times of political violence. Hybridity and shape shifting are recurrent motifs in postmodern novels and 
can be closely linked to parody and mockery. In Grass and Rushdie, hybridity is used in particular to mock the ideas of purity and the zero hour of the nation state, which imply forgetting, a historical tabula rasa. Like Oskar Matzerath, Saleem is a highly heterogeneous creature, an embodiment of diversity and pluralism. It is this impurity of his identity that points to the nation-state itself, to India before and after 1947, the year of independence, as pluralism and heterogeneity are aspects that are consistent on both sides of this historical event. Both Grass's and Rushdie's texts are destabilizations of the notion that with the new nation-state comes a new beginning that tends to forget what happened before. "We are a nation of forgetters" (MC 43). Rushdie's words also apply to post-war Germany in the 1950s, and to Konrad Adenauer's government's insistence on rationalism and cultural conservatism as a reaction against the Nazi years it perceived as solely irrational.

Rushdie's novel is a work of pastiche. As such it is typically postmodern, literature patched together from other literary texts. Using Grass's Tin Drum and the German postwar cultural-political situation as a model, Rushdie copies Grass in reenchanting a secularized country grappling with the memory of genocide through a set of mythological paradigms. By drawing on postcolonial theory and the biopolitical concept of the homo sacer this essay analyses Rushdie's particular brand of what I have termed as mythical realism in view of its close amalgamation of hybridity with mimicry, subversive mockery, and liminality between the human and the animal, typical features of the postmodern novel trying to come to terms with war and genocide. It is the aim of this study to examine the functions of these key features for Rushdie's Midnight's Children for lifting the corks of forgetting and disclosing the concealment of India's past.

\section{Hybrid mythical bodies}

Midnight Children abounds in open, grotesque body images à la Bakhtin, which as John Clement Ball has pointed out, are "referentially directed towards the qualities of Indian society that Rushdie valorizes: pluralism, democracy, hybridity, and change" and they satirically attack the "forces in modern India and Pakistan that deny those principles: fundamentalism, despotism, purity, and stasis" (Ball 73-4). Reaching his full adult height within a year when he is only eleven and half years old Saleem Sinai is clearly inspired by Oskar's physical stasis and later transformation. Passages such as Sinai describing his "lengthening limbs ... making me clumsy, and I 
must have cut a clownish figure" (MC 352) evoke not only Grass's protagonist but the trickster archetype in general, his hybridity and flexible joints (Hyde 252-80). So do the flexible and destructive knees of Saleem's alter ego Shiva, with whom he gets switched at birth. These bodily images are clearly part of trickster mythology, as are Saleem's picaresque wanderings from India to Pakistan, to the East Wing, and then back to India, the garrulousness of Ganesh whom he resembles in his facial features, and many of the characteristics attributed to the 1001 children born on or around the stroke of midnight preceding the day of Independence. Of these children 420 die the number of trickery, fraud and deception (MC 272). Many of them, including Saleem, are monsters (MC 273) in the Foucaultian sense of a duality of features, finding themselves caught in a liminal space, of children with two heads or bull's horns or the crossover between human and animal ${ }^{1}$.

By way of his Ganesh-like facial features Saleem may initially only represent the Hindu side of the Indian nation, but much like in Grass's novel, where the hunchback Oskar is a mythical representation of the nation state, the body images in Midnight's Children contain a political message in aligning the protagonist with the newly formed nation. As his teacher Zagallo points out in his lesson on human geography, Saleem carries the very shape of the Indian subcontinent in his face:

Thees object here' - a tug on my nose - 'thees is human geography!' [...] 'In the face of thees ugly ape you don't see the whole map of India?' [...] 'See here - the Decan peninsula hanging down!' Again ouchmynose. 'Sir sir if that's the map of India what are the stains sir?' [...] And Zagallo, taking the question in his stride: 'These stains,'he cries, 'are Pakistan! Thees birthmark on the right ear is the East Wing; and thees horrible stained left cheek, the West! Remember, stupid boys: Pakistan ees a stain on the face of India!' 'Ho ho,' the class laughs, 'Absolute master joke, sir!' But now my nose has had enough; staging its own, unprompted revolt against the grasping thumb-and-forefinger, it unleashes a weapon of its own . . . a large blob of shining goo emerges from the left nostril, to plop into Mr Zagallo's palm. Fat Perce Fishwala yells, 'Lookit that, sir! The drip from his nose, sir! Is that supposed to be Ceylon?' (MC 321)

\footnotetext{
1 Foucault, Abnormal, p. 63: "monsters...It is the blending, the mixture of two species [man and bull]... It is the mixture of two individuals: the person who has two heads." The iconography of the satanic is part of the trickster myth, the horns in later cultural traditions becoming replaced by the fool's, the Harlequin's or Till Eulenspiegel's two-horned cap.
} 
Rushdie's mythical realism easily fits Bakhtin's description of carnivalized literature with its celebration of the grotesque body, its polyphony or heteroglossia, its subversive, anti-authoritarian thrust, and its indebtedness to the ancient Roman menippean satire, a genre steeped in myth. Rushdie's use of the grotesque and revival of myth are directed against the stasis and despotism of modern India, specifically the postcolonial view that independent India was to become a secular state not in need of myths. A mythological paradigm such as a character's transformation from a human into an animal functions as a way of re-enchanting a secularized society whose rulers stress the forces of reason as glossing over those of irrationality. Saleem Sinai's hybridity between the human and the animal, however, is an ambivalent process. He transforms from a benign and sacred emblem, the Hindu Elephant God Ganesh, into a sacrilegious and negatively connoted hybrid, that of a Muslim man dog in the context of the political tensions between India and Pakistan².

Although derived from Hindu mythology, Saleem's physical attributes are also derived from François Rabelais, and this is where the connection with Bakhtin's carnival is justified. 3 After all, Rushdie's own hybrid identity extends from India to Europe. Bakhtin's carnivalized, open body is a hybrid mythical body, whose principal grotesque features are protruding body parts such as the nose. Saleem's prominent nose, with which he can smell the thoughts of others and even subterranean mines and bombs, is both a Hindu and a Rabelaisian feature. As the latter it is reminiscent of the nose of Friar John in Rabelais's Gargantua (Rabelais 127). While Grass was directly influenced by Rabelais as he was reading the latter when he started writing The Tin Drum in Paris, the similarity between Rushdie and Rabelais results from a wider intertextual web that includes ties to both European and Indian mythology. This symbolism of fertility in the physical attributes of the protagonists in Rabelais, Grass and Rushdie functions as a set of counter-images to political monologues that stifle all spiritual fertility in the sense of alternative versions of history and ideology.

\footnotetext{
2 The dog man as a derivative of the wolf man intertextualizes this novel also with Michel Tournier's novel The Ogre (1970) and his protagonist Abel Tiffauges, the ogre turned saint, the cynocephalus (dog head) St Christopher, as well as with Isabel Allende's patriarch Esteban Truebas in The House of Spirits (1982). Physical hybridity in these texts is closely linked to cultural memory and the notion of shattering the manacles of forgetting, of political and public lethargy in the face of history. As elephant man Saleem's physiognomy is as expressive of the nation at large as is Oskar Matzerath's hump, Germany's guilt that he carries on his back.

3 Cf. Bakhtin, Rabelais and his World, especially his chapters on the grotesque body.
} 
It is precisely this fertility that Bakhtin held against the stifling party monologue of Stalinism.

The notion of fertility is as closely tied to the hybrid open body, the body that grows beyond its given contours, as it is to mythical, pre-modern India still void of the kind of technological progress and business sense of the twentieth century that Rushdie sees in contrast with myth. On the one side of the spectrum we have Dr Narlikar, the "opponent of fertility" (MC 244) and admirer of concrete, with whom Saleem's father Ahmed Sinai works together on the project of gaining land from the sea in Bombay, while on the other side there is Saleem, who embodies myth. His nose/Ganesh's trunk is a key symbol of fertility; it is phallic and associated with the root of feronia elephantum (MC 268), an herb of virility. The connection with Oskar's hump, which women love to touch, is particularly close here.

Hybridity, in the sense of an open growing body, the body in the act of becoming, versus shrinkage and loss of fertility are also gender categories in Midnight's Children, as they are in Grass's novel. While Saleem displays a certain androgyny (MC 375f), Padma whom he tells his story is rather masculine: "Why I have chosen to expound on Padma's musculature ... it's to those muscles that I'm telling my story" (MC 375). Women tend to be stronger than men in this novel, and as Saleem's grandfather declines physically, his grandmother, "Reverend Mother grew larger and stronger" (MC 381). "Moustachioed, matriarchal and proud ... she [the Reverend Mother] grew, with alarming rapidity, wider and wider" (MC 456). The pair recalls Oskar's grandparents, specifically his grandmother, the magna mater archetype, who shelters men in trouble under her four skirts, the great womb. Saleem's grandfather has become like a child again (MC 383), and his shrinking points to other novels of mythical realism, specifically to Isabel Allende's House of the Spirits (1982), where Esteban shrinks after his body is almost destroyed by an earthquake. In all three novels, patriarchy subsides and makes room for a matriarchy, which is also visible in the intense suffering that Esteban's granddaughter Alba can sustain physically.

Hybrid bodies are open to fragmentation and reassembly, as the Dionysus myth already makes clear. Fragmented bodies, even translucent bodies, also occur in Midnight's Children. The Sinai family seems to be "condemned by a perforated sheet to a life of fragments" (MC 165). It appears first of all in the image of the perforated sheet, which allows only a seven-inch glimpse of a fraction of the woman's body at a 
time, and that sets a leitmotif for the novel. It then reappears in Amina, Saleem's mother, learning to love her husband Ahmed piece by piece: "she began to train herself to love him. To do this she divided him, mentally, into every single one of his component parts" (MC 87). The fragmented body reflects the postmodern condition per se, its loss of totality, and as such it too represents the Indian nation-state, the many-headed monster with its ethnic and religious mishmash that in the course of Indian history has led to clashes and even acts of genocide. Thus the open, in this case fragmented body, can also become a metaphor for racial conflict. "History pours out of my fissured body" (MC 45).

This fragmentation of the body reflecting the nation-state as a whole goes hand in hand with the Bakhtinian idea of heteroglossia, of a multiplicity of voices which contrasts with the idea of purity. The body as a representation of the nation, the Nazis called it the Volkskörper, becomes visible in nuce in the representation of the city of Bombay as a body, thus echoing the idea of the Greek polis, the city as people: "Our Bombay: it looks like a hand but it's really a mouth, always open, always hungry, swallowing food and talent from everywhere else in India” (MC 171f). Bakhtin's grotesque body with its openings and protrusions is reflected in the very image of Bombay. The protagonist and his city are thus part of the same carnivalesque principle, something we also see at work in The Tin Drum, where at least some of the architecture forms a close symbolic unity with Oskar, if we look at the Stockturm from which Oskar can see the whole city - "Danzig - venerable city of many towers, city of belfries and bells, allegedly still pervaded by the breath of the Middle Ages" (Grass 103) - and from where he is screaming glass to pieces. While Oskar's open mouth symbolizes protest against the adult world and their shabby little stories whether private or public, Bombay's open mouth stands for hunger, as the passage above makes clear. Oskar's 'madness' on the Stockturm occurs historically speaking in the right place, for during the Middle Ages and the Renaissance the insane were locked up in so-called Narrtürmer (fool's towers, Foucault, Madness, 9). His open mouth, as we have seen, is also an image for this animality, as he is all emotion when he screams, and not logos, which is at the heart of enlightened humanity with its Descartian dictum of cogito ergo sum.

With its heterogeneity and heteroglossia Bombay reflects the Bakhtinian carnival far more than does Gdansk, which in comparison displays a somewhat reduced heteroglossia with its German, Polish and Cashubian cultures. As the nation 
becomes embodied in the protagonist, the city also has a close connection with the hybrid body, especially in Rushdie. We are familiar with this concept of an intimate relationship between the human/animal hybridity and the city in the context of Rome and its foundation myth. The wolf-reared children may on the one hand be a symbol of strength, but the idea of impurity is implied in the very hybridity of the wolf as both animal and person, if we remind ourselves that the lupa romana may also have been a prostitute, as the word lupa (she-wolf) indicates a prostitute in Roman dialect. Bombay is "multitudinously shapeless" and its heteroglossia is a linguistic and mental echo of the body in fragments. These mythical bodies and cities - as I would call them - are opposed to the idea of purity. In Rushdie's novel Karachi is expressive of such purity, and in the German context the National Socialist idea of the nation as body, the Volkskörper, also envisions purity and homogeneity. The racial homogeneity of a Thousand Year Reich contrasts sharply with the ethnic tapestry of India, specifically Bombay/Mumbai. This racial and religious hybridity is then embodied in nuce by Saleem himself, the Muslim with the Hindu elephant trunk (MC 206).

Dialogicity and heteroglossia present alternative ways of seeking truth and are opposed to "official monologism, which pretends to possess a ready-made truth" (Bakhtin, Dostoevsky, 110), truth born between people, not inside the head of any one person. Saleem hears the many-headed monster in his head, as he acquires the gift of hearing any voice in India (MC 232), a passage that would testify to the proximity between Bakhtin's notion of polyphony and truth seeking on the one hand, and mythical realism's creation of alternative realities and truths directed against the monolithic truths created by state rulers. The many-headed monster of India contracted in Saleem's brain closely connects his body to the body of the nation. He incorporates it, as it were, much in the way as Oskar incorporates German guilt, the nation as a whole, in his hump, expressive of the ugliness of Nazi monoglossia and its dire consequences 4 .

\section{Mimicry}

\footnotetext{
4 Saleem's transformation recalls not only Oskar's own transformation in the railway car but also the transformations of other characters in fiction of mythical realism. Franz Kafka's Gregor Samsa may come to mind. Kafka's Metamorphoses partakes of the genre of mythical realism, as the protagonist's hybridity of body and mind is an attribute of the shape-shifting trickster archetype at the root of satirical literature.
} 
Hybridity, however, extends beyond the body in Rushdie's novel. In postcolonial discourse the idea of hybridity is also closely linked to mimicry, mockery, and ultimately subversion. Mimicry, mockery, and subversion are key features of the human/animal liminality in the postmodern satirical novel about war and genocide. In colonial and postcolonial texts mimicking the colonizers implies that the colonized become hybrids between themselves and the rulers, an extension of the physical hybridity described above. Colonialism creates its own mimic men, as does fascism, as one can observe, for example, with the Kapos Primo Levi describes in his testimony If this is a Man (1947). The colonized mimicking the colonizers may lose their originality, but through mimicry they have the power to threaten colonial authority and subvert the colonial system from within. These mimic men then become a menace to the colonizer. Mimicry as repetition, as copy, threatens to decenter original authority. In the act of repetition originality is lost, centrality decentered, its authoritarian language questioned. As Bakhtin put it: "We may even say that language and languages change historically primarily by means of hybridization" (Bakhtin, Dialogic Imagination, 358). By language, of course, one needs to keep in mind that it is a system of utterances, a discourse of power that is being subtly subverted by mimicry and the hybridity it entails. What is left after mimicry, according to Bhabha, is semblance rather than essence, a trace, the impure, the second-hand. Colonial power thus implies originality. Dominant culture is contaminated by the linguistic and racial differences of the native self. This is hybridity in Bhabha's sense, who goes beyond Frantz Fanon's Black Skin, White Masks, a text that does not contain the subversive element in the colonized's emulation of the colonizer (Bhabha, 'Of mimicry and man').

By mimicking the colonizer the colonized can mock him. Mimicry and hybridity are key elements of texts posing as counter-narratives to colonial power. We see this clearly reflected in some scenes in Rushdie's Midnight's Children, for example, at the moment when the imperialist Methwold sells his estate to the Sinai family, and the colonizer becomes metaphorically displaced by the colonized: "I am transferring power, too. Got a sort of itch to do it at the same time the Raj does. As I said: a game" (MC 127). A post-colonial game, one might add, by which Methwold simultaneously refers to a continuity of the Great Game of colonialism as Kipling had described it in Kim (1901). A game that was not a game to the colonized while colonialism lasted, who now, in turn, however, also play a game with the colonizer, a 
game of mimicry and mockery. Can colonial mimicry/mockery be compared to theories that engage with subversiveness in other power systems? Bakhtin's Rabelais book, for example, was a mockery of the monologue of Stalinism, without, however, mimicking it. Yet the Bakhtinian notion of mockery is based upon the presence of hybridity (primarily the open body) and polyphony by which a given power discourse is being challenged, if not subverted. It is this type of mockery that becomes audible in the voices of the formerly colonized, now enriched and empowered - Ahmed Sinai and his wife Amina. Ahmed's changed voice in the presence of Methwold, "in the presence of an Englishman it has become a hideous mockery of an Oxford drawl" (MC 127) is itself fraught with colonial ambivalence: on the one hand, this sudden adaptation of an accent reveals the colonized still in the habit of emulating the colonizer. On the other hand, however, the fact that it is mimicry as a mockery of the colonizer's voice points to the new reality, that now the colonized has literarily "appropriated the Other [the colonizer's estate] as [his mimicry] visualizes power [through the change-over of the estate and in this case makes audible through the change-over of voice] ... the excess or slippage produced by the ambivalence of mimicry (almost the same but not quite) does not merely rupture the discourse, but becomes transformed into an uncertainty which fixes the colonial subject as a partial presence" (Bhabha 86). The excess or slippage in the ambivalence of Ahmed's mimicry does actually more than just fix the colonial subject, i.e., Methwold, as a partial presence. In its faculty of mocking Methwold the fake Oxford accent already announces the colonial subject's impending absence from the colonial terrain. This impression of the colonized's displacement of the colonizer, of his ultimate superiority over the colonizer is driven home especially by Amina's reactions to the purchase of the estate, her repeated interruption of her husband's voice through her own more direct voice, one that is completely void of mimicry but announces the self-confidence of the well-endowed Indians as the new rulers of their own country: "And look at the stains on the carpets, janum, for two months we must live like those Britishers? [i.e., until the house is changed according to their own taste] You've looked in the bathrooms? No water near the pot. I never believed, but it's true, my God, they wipe their bottoms with paper only!" (MC 127). While Ahmed keeps a straight face and upholds a façade of politeness partially as a relic of deference that the colonized may have had for the colonizer, while he may still believe that " $\mathrm{Mr}$ Methwold is a fine man; a person of breeding, a man of honour," his wife's reaction 
reveals a view upon the colonizers as savages, i.e., which in a way is similar to the stereotypical perception the colonizers once had of their colonial objects. She demonstrates how in the great colonial game the colonizer himself can become a mimic-man of the colonized, in going native so to speak, as the stains on the carpets point to a reversal of the traditional stereotypical and Orientalist roles between colonizer/colonized of the former being immaculate and emerging from Europe with a civilizing mission, while the latter, the purported savages, are messy and in need of reform. In the change-over of power at the Methwold Estate it will be the other way round. After the messy British have left the colonial object as new master will have to clean up and a more civilized life-style will move in.

The idea of mimicking those in power with the intention of subverting that power from within is a concept that is not limited to the context of colonialism/postcolonialism but can also be applied to fascism. It occurs in Grass's The Tin Drum, specifically at the moment when Oskar starts drumming. This drumming has been seen as mimicry of fascism (drumming) in the sense that Hitler was also called the drummer and there was a lot of drumming going on at Nazi party rallies. The subversive act of Oskar's drumming in imitation of fascist drumming happens primarily in the rostrum chapter scene where he sits under the bandstand and first joins the music above but then goes on to disrupt its monotonous rhythm through his own wilder rhythms. Read in this context Oskar's infamous scream is likewise a grotesque deformation of the noise with which National Socialism enters every stage. The "prophet-aping" (MC 232), English-aping, grotesque mimicry of religion and colonialism in Rushdie's novel is just as Bakhtinian, or rather Rabelaisian, if one keeps in mind that Rabelais's social criticism is targeted against the institutions of Church and State. Rushdie's novel shares this with Grass who is critical of the Adenauer period, retrospectively of fascism, but continually also of the Catholic Church and its reluctance to resist National Socialism, as our comments on blasphemous church scenes have shown in more detail.

Mimicry and mockery are not limited to the colonial context in Rushdie's text. They also fill the chapters on the historical conflict between India and Pakistan. Mockery becomes rather intense here. In terms of its attacks against Islamic Pakistan, one could argue, Midnight's Children is a precursor of Satanic Verses. The key chapters in view of blasphemy are the ones about Jamila Singer, as Saleem's sister is called by the Pakistani, and about Saleem turning into a 'man dog.' In 
Pakistan, the Land of the Pure, Saleem's sister undergoes a radical change from Brass Monkey to a demure Islamic woman who is exploited for the clarity and purity of her voice. In line with the trickster archetype in the Ramayama she carries the name Brass Monkey as long as she is her flippant Indian self, and before becoming purified of her trickster features. The blasphemy becomes rather intense with the allusion to incest on these pages, as in the Land of the Pure Saleem discovers that he is erotically attracted to his sister: "It was not long after my arrival in the 'Land of the Pure' that I discovered within myself the ultimate impurity of sister-love" (MC 427). The Land of the Pure, Rushdie seems to argue, is so pure that incest is the ultimate expression of such purity. Incest is a ubiquitous topic in the genre of mythical realism and occurs also in Allende's House of Spirits (1982), Garcia Marquez's One Hundred Years of Solitude (1967), and Grass's Tin Drum (1959).

But Rushdie provokes not just with regard to his grotesque characters. The city of Karachi itself is described as a deformed city full of "deformed houses, the stunted hunchback children of deficient lifelines ... proliferation of madhouses" (MC 429). Karachi's ugliness and monoglossia contrast starkly with Bombay's heterogeneity and heteroglossia. The mockery, which Bakhtin defines as a levelling of officialdom by carnivalesque non-conformity, is played out in the pair of the two cities Mumbai and Karachi, the former remembered by the protagonist in its "highlyspiced non-conformity" (MC 428), whereas his new fellow-citizens in Karachi "exuded the flat boiled odours of acquiescence" and had a faith that was based upon submission. Forever tainted with Bombayness Saleem suffers from the purity, which became our ideal, as he says (MC 431), purity, that is, in a religious sense. And yet this religious purity is a power structure that also stigmatizes its misfits. Saleem is as much a misfit in this place ("I was doomed to be a misfit" [MC 431]) as is Oskar Matzerath in fascist Germany. Until purity finds him out and cleanses him of his misdeeds, Saleem engages in trickster dirt work, in all sorts of provocative impurities by which he tries to taint the Land of the Pure. His nose, that key emblem of Hindu myth, acquires a certain centrality in these provocations. In Rabelais's Gargantua and Pantagruel, too, noses tend to not only protrude but also mock and disturb classical form. While Saleem's nose engages in profanities, his sister's voice (inspired by Oskar's voice phenomenon?) becomes an emblem of the sacred: "My nose, her voice: they were exactly complimentary gifts...she rose into the clouds, I fell into the gutter" (MC 438). Islam outlaws the grotesque body as the revealed body, while 
Jamila Singer's concealed body (Pakistan glimpses her through a gold and white perforated sheet [MC 435]) from which emanates her angelic voice is the ideal. Saleem, on the other hand, explores profanity and lust and noses out the whore of whores, Tai Bibi, who claims to be five hundred and twelve: “I don't care about your age, the smell's the thing" (MC 443). He gets aroused by the corns of this "impossible mythological old harridan" (MC 444) who smells like both his mother and his sister. To say it with Bakhtin: the lower bodily stratum may be profane in Pakistan but it is sacred in India, if we think of the sacred dung of cows ("Dung, whose arrival from the nether end of cattle goes a long way towards explaining their divine and sacred status," MC 35). The novel of mythical realism plays with these two paradigms, the sacred and the profane, and inverts them happily. While in Rushdie the profane, the lower bodily processes, is sacred, at least in the context of cows in India, in Grass's novel, we see a different process at work in that the sacred is profaned, for example in the church scenes; the same, however, happens in Rushdie in the profanation of Islam in the Pakistan chapters.

Islamic purity thus clashes with Hindu hybridity. Yet the purity of incest is also particular to myth, at least to early religious accounts such as the story of Adam and Eve and their subsequent generations, which strictly speaking all partook of incest, simply because there was only one clan. Rushdie reveals this connection between the foundation myth and religion, implying that all religious claims of moral purity are hypocritical due to the purity/impurity of the original sexual act. The name 'Land of the Pure' is in the end justified through nothing else but purity in a sexual sense of incest, the limited racial sense of blood of the same family. There is therefore a link between the religious incestuous notion of purity of this postcolonial novel and the racial purity in fascism that if taken to a further extreme than it went in the twelve years of the Third Reich would have resulted in incest (the Ikarus flight of Nazi racial ideology). Rushdie understands purity, however, also as a void of that infinity of alternative realities that he sees in India, while Pakistan is described as having the monopoly of untruth, although a little bird in his ear sings of scepticism. Mythical realism is the genre that opens the view to a multiplicity of alternative realities in the face of a despotic usurpation and dissemination of official truths.

\section{Homo Sacer}


It is in this context of switching sides from Hindu Bombay to Muslim Karachi and of engaging in anti-Muslim profanities that Saleem becomes the homo canis, the dog man or man dog. Homo canis, like the Icelandic vargr (wolf and outlaw), that hybrid between the human and the wolf, is the homo sacer as Agamben has described him, sacred in the sense of being cursed by and expelled from the community (Agamben 104). He shows the typical hybridity of this figure, its duality of being hounded and hounding others, a wolf in the sense of being a Muslim who is expelled from Bombay as well as a wolf to others, part of a pack that tracks undesirables.

The homo sacer is set aside from society, and breaks with the sacred by turning purity into impurity. As is typical of this figure expelled from the community his transformation is connected to oblivion, to what ancient Greece understood as the concept of Lethe, and to the kind of speechlessness that we observe as early as in Lycaon, the King of Arcadia whom Jupoter turns into a wolf for breaking the taboo of cannibalism. The homo sacer is closely tied to the sovereign with whom he shares his status of being above or beyond the law. This relationship between the despot and his victim replicates the bond between colonizer and colonized, the mimicry by the latter of the former. I would argue that colonial mimicry as Bhabha defines it shows certain parallels with the so-called Wolfsfreiheit the homo sacer enjoys, his freedom from outside the social contract. Through that freedom, in his lawlessness, the outlaw mimics the despot in similar ways as the subaltern mimics the colonizing sovereign. As free as a wolf, homo sacer is a Waldgänger in the sense of Ernst Jünger's use of this philosophical term (Jünger, Der Waldgang) as someone who distances himself from society, able to attack it from its margins. In Saleem's case, his journey through the Sundarbans forest has that function, his Waldgang designed to lift the cork of concealment and forgetting and to reveal his own past and the trauma of genocide.

In Pakistan Saleem acquires a new hybridity. He is no longer just part man, part elephant god, but now hybridizes into a creature that is divided between two mythical paradigms, part Hindu and part Muslim "man-dog” (MC 484), both Hindu victim and Muslim persecutor. As the two personalities conjoin with his past in India buried by a fit of amnesia he becomes a Muslim mimic man. After Saleem and his family are bombed in the 1965 war between India and Pakistan over Kashmir, he loses his memory and thus all sense of the past and of history. This gains him the nickname 'Buddha' and man dog as he enlists in the Canine Unit for Tracking 
Intelligence Activity (CUTIA). Rushdie embeds this figure into a representation of politics and history. As man dog the Buddha "learn[s] the art of submission, ... bec[o]me[s] a citizen of Pakistan" (MC 488) and thanks to his Hindu nose can smell the mines in the Pakistani Hindu war5 and is able to root out subversiveness: "dogsoldiers strain at the leash, and then, released, leap joyously to their work. $\mathrm{O}$ wolfhound chases of undesirables! O prolific seizings of professors and poets! ... Smell this! That's the stink of subversion! - unleash the war-hounds of unity? There are things which took place on the night of March $25^{\text {th }}$ which must remain permanently in a state of confusion" (MC 497f). Rushdie refers here to the occurrences on the 25th of March when rising political discontent in East Pakistan, now Bangladesh, was brutally beaten down by West Pakistan in what was encoded as 'Operation Searchlight,' acts of genocide committed against the Bengali and Hindu population of Bangladesh. Especially students, intelligentsia, and able-bodied men were killed: O prolific seizings of professors and poets! It was the beginning of the third Indo-Pakistani War which broke out on 26 March 1971 and led to purges of Hindus in the East wing and consequent mass migration from there into the East Indian provinces. Bengali military, paramilitary and civilians formed the Mukti Bahini, rebel forces that received military, economic and diplomatic support from India. This in turn led to the West Pakistani Operation Genghis Khan, a pre-emptive strike on the West Indian border. On the 16 December 1971 the Indian army and the Mukti Bahini defeated the West Pakistani forces deployed in the East. The IndoPakistani war resulted in the secession of East Pakistan, which became the independent nation of Bangladesh.

Although officially working on the side of the aggressors, Saleem retains the duality of oppressor and persecuted undesirable. His nickname Buddha implies the very antithesis of an ideology that insists on history and memory of the past. We have seen how Saleem breaks with the sacred when he discovers in the smell of a whore the smell of his mother and sister. In this image of sister love purity and impurity are conjoined, genetic purity with moral impurity. The sacred is often associated with purity but it can be quite impure, as we can see in the example of cow's dung, which

\footnotetext{
5 Saleem is not the only "wolf man" in this book. There is also Joseph D'Costa, the social radical who later becomes a ghost who compels Mary Pereira to confess her crime of having switched Saleem and Shiva as babies so that each ends up with the parents of the other: "Joseph is there each night, sometimes in human form, but not always, sometimes he's a wolf...howling at her when he's a wolfJoseph" (236).
} 
is sacred and impure at the same time. So is the homo sacer, impure because of his hybridity of body and identity, but also to the gods, and thus sacred. He is sacred not in the sense in which the dung of cows is sacred in Hindu belief, but rather sacred in the ancient sense of the concept as someone who is "set apart" from common society, someone who is 'cursed.'

The sacred man is the one whom the people have judged on account of a crime. It is not permitted to sacrifice this man, yet he who kills him will not be condemned for homicide; in the first tribunitian law, in fact, it is noted that "if someone kills the one who is sacred according to the plebiscite, it will not be considered homicide". This is why it is customary for a bad or impure man to be called sacred. (Agamben 71)

Saleem's hybrid postcolonial identity of man dog covers over his original Indian identity, which is indicated by the Ganesha connection. The postcolonial age is characterized by similar processes of amnesia (Stunde Null) as post-fascism. This amnesia is a phenomenon that also springs from the urge to establish purity. The text satirically attacks this concept of purity. Saleem as a new citizen of Pakistan is only nominally pure as he is working for the Land of the Pure. His hybrid identity of Anglo-Indian Muslim with Hindu facial features and finally man dog (considered unclean by Muslims) screams with impurity. This irony is supported by the fact that he represents what he persecutes. This schizophrenia of the homo sacer is an integral part of his hybrid, monstrous nature and in Rushdie's text becomes particularly apparent as Saleem and his accomplices are travelling through the Sundarbans swamps, where "they no longer know if they are chasing after or running from" (MC 501). Hybridity in this novel extends past bodies, identities, cities to two border areas, the Rann of Kutch and the Sundarbans. All of these paradigms of hybridity combine for the overarching satirical purpose of revealing the absurdity of purity and the Stunde Null, the zero hour of a nation oblivious of its past.

It is no coincidence that the two principal landscapes experienced as hybrid are located in the border regions of Pakistan and India, the Rann of Kutch between the West Pakistan wing and India, a borderline area also in the sense of being amphibian: a "chameleon area half land half sea" (MC 395), as well as the amphibian terrain of the Sundarbans swamps, the delta area of the Ganges River shared by India and Bangladesh, formerly East Pakistan. Both regions are dense with 
mythological allusions. The Rann of Kulch is disputed territory, like the Sundarbans a hazy phantasmagoric area of forgetting (MC 465), a mythological landscape that has fish women that are like sirens, "tempting the unwary into fatal sexual acts" (MC 466). The Sundarbans landscape with its hybridity in a geological sense is also a landscape of myth par excellence, and has much in common with other texts of mythical realism, especially of Latin American provenance with their jungle landscapes (One Hundred Years of Solitude, eg). Grass's The Tin Drum, however, also contains a hybrid landscape, although in an ethnic sense, Cashubia, the area around Gdansk with its population that is neither quite Polish nor quite German. In comparison, Bakhtin notes that Petersburg in Dostoevsky is a city "on the borderline between existence and nonexistence, reality and phantasmagoria, always on the verge of dissipating like the fog and vanishing” (Bakhtin, Dostoevsky, 167). This borderline state between existence and nonexistence, visibility and invisibility is typical of the trickster archetype and carnival (the use of masks too). Such amphibian terrain is trickster terrain, as tricksters are amphibians, borderline or threshold creatures. Space in carnival and for the trickster is located around thresholds, in the case of the Sundarbans the threshold between land and sea but also for the characters who roam this area in half-madness, between visibility and invisibility. In the Sundarbans Saleem and his fellow trackers become physically transparent (MC512), a detail that reflects Bakhtin's open body ad extremis.

The dissolution of physical confines is a mythical element denoting the ancient Greek concept of lethe in its triple signification of concealment, forgetting, and destruction. In many literary texts from the German Romantics to the postWorld War II period and its literature about the camps (Michel Tournier's The Ogre, e.g.) the revelation of acts of atrocities tends to happen in the forest. It does in Rushdie's novel, too, where physical translucency precedes the transparency of the past and atrocities are revealed:

There was a small pyramid in the middle of the field. Ants were crawling over it, but it was not an anthill. There pyramid had six feet and three heads and, in between, a jumbled area composed of bits of torso, scraps of uniforms, lengths of intestine and glimpses of shattered bones. The pyramid was still alive. One of its three heads had a blind left eye, the legacy of a childhood argument. (MC 520) 
The fragmented bodies as we see them in this scene are a historical alternative to the mythical, dissolved bodies in the Sundarbans. As a variant of the Bakhtinian open body, they are mythically realist in that they reflect a historical reality, ethnic cleansing, but also imply an allusion to myth. According to Bakhtin the body's tearing to pieces is typical of carnival in the sense of a "sacrificial dismemberment into parts." He points out that this "carnival anatomy - an enumeration of the parts of the dismembered body" (Bakhtin, Dostoevsky, 162) was a common device in the Renaissance. I would argue that the carnival in Bakhtin is as ambivalent as the Dionysian state of intoxication in Nietzsche's The Birth of Tragedy (1872). Carnival and the Dionysian Rausch (intoxication) trigger not only moments of laughter and joy, but they also produce terror. After all, the carnival is grounded in the iconography of the satanic. The Bakhtinian carnival also implies the notion of carnage. In Grass's novel we hear the mad laughter of the perpetrators, the madness of Rasputin, of Dionysian excess, as the death of four thousand children in the gas chambers is evoked by the daunting image of the merry-go-round in the chapter "Desinfektionsmittel" (Disinfectant) and we hear the laughter of persecuted Oskar. Although his laughter functions as comic relief it also contains terror and madness.

The dissolution of mind and body in the Sundarbans chapter evokes the Dionysian principle with its "transgression of limits, the dissolution of boundaries, the destruction of individuality" (Nietzsche xi), which "vanish[es] to the point of complete self-forgetting" (Nietzsche 17). As man dog, sniffer of undesirables, Saleem is intoxicated and indoctrinated to the point of self-forgetting. The Sundarbans episode brings this disintegration to a peak, tying physical disintegration to that of the mind: "They had all long ago forgotten the purpose of their journey" (MC 506), "the buddha (Saleem) had forgotten his name" (MC 509). The image of the pyramid of body parts then is the culminating reminder of the fragmentation and dissolution of subjectivity happening in the protagonist during his work for the Land of the Pure, and triggers the return of the repressed before he regains his memory and reintegration of his subjectivity. Although dissolution and disappearance mark the Sundarbans forest as a place in which things are secretive and covered up, it is ultimately a place of revelation and resistance to secrecy, concealment, and denial. This revelation of history through mythical-realist narratives and the notion of hybridity marks other texts in Rushdie's work, such as his short novel Shame (1983), where the narrator describes how the Partition leads to a rewriting of Pakistan's 
history and how centuries of Indian history in Pakistan were covered up and buried in the past. In the end, Saleem as man dog may forget his own past, that of his family and country, but the snake that bites him in his heel awakens the Hobbesian spaniel of remembrance in him (Hobbes 22), who ranges the field of lethe until he finds a scent. 


\section{References:}

Agamben, Giorgio. Homo sacer: Sovereign Power and Bare Life. Palo Alto: Stanford UP, 1995 .

Bader, Rudolf. "Indian Tin Drum," in: The International Fiction Review, vol. 11.2 (1984): 75-83.

Bakhtin, Mikhail. Rabelais and his World. Bloomington: Indiana UP, 1984.

---. Problems of Dostoevsky's Poetics. Ed. and trans. by Caryl Emerson. Minneapolis: U of Minnesota P, 1984.

---. The Dialogic Imagination: Four Essays by M. M. Bakhtin, Ed. Caryl Emerson, Michael Holquist. Austin: U of Texas P, 1981.

Ball, John Clement. "Pessoptimism: Satire and the Menippean Grotesque in Rushdie's Midnight's Children,” English Studies in Canada, 21.1 (1998): 61-81.

Bhabha, Homi K. "Of mimicry and man: The ambivalence of colonial discourse," in The Location of Culture. London/New York: Routledge, 1994. 85-92.

Couto, Maria. “'Midnight's Children' and Parents,” in: Encounter, vol. 58.2 (1982): 61-66.

Foucault, Michel. Abnormal. Lectures at the Collège de France 1974-1975 (London, New York: Verso, 2003.

---. Madness and Civilization. New York: Random House, 1988.

Gopal, Raj. Saleem Snotnose und Oskar der Blechtrommler. Zum Vergleich von Günter Grass und Salmon Rushdie, in: German Studies in India. Trivandrum: University of Kerala, 1983.

Grass, Günter. The Tin Drum. Translated by Ralph Manheim (1961). New York: Vintage, 1990.

Herd, E. W. “Tin Drum and Snake-Charmer's Flute: Salmon Rushdie's Debt to Günter Grass,” in: New Comparison, vol. 6 (1989): 205-18.

Hobbes, Thomas. Leviathan. Ed. by Richard Tuck. Cambridge: Cambridge UP, 1996.

Hyde, Lewis. Trickster Makes this World. North Point P: New York, 1998.Jünger, Ernst. Der Waldgang. Stuttgart: Klett-Cotta, 1980.

Merivale, Patricia. "Saleem Fathered by Oskar: Intertextual Strategies in 'Midnight's Children' and 'The Tin Drum,"'in: Ariel: A Review of International English Literature, vol. 21.3 (1990): 5-21. 
METACRITIC JOURNAL FOR COMPARATIVE STUDIES AND THEORY 3.2

Nietzsche, Friedrich. The Birth of Tragedy and Other Writings. Ed. Raymond Geuss and Ronald Speirs. Cambridge, Cambridge UP, 1999

Rabelais, François. Gargantua and Pantagruel. Harmondsworth: Penguin, 1955.

Rushdie, Salman. Midnight's Children. London: Vintage, 2006. 